\title{
The role of biogas solutions in sustainable biorefineries
}

Linda Hagman, Alyssa Blumenthal, Mats Eklund and Niclas Svensson

The self-archived postprint version of this journal article is available at Linköping University Institutional Repository (DiVA):

http:// urn.kb.se/ resolve?urn=urn:nbn:se:liu:diva-143022

N.B.: When citing this work, cite the original publication.

Hagman, L., Blumenthal, A., Eklund, M., Svensson, N., (2017), The role of biogas solutions in sustainable biorefineries, J ournal of Cleaner Production.

https:// doi.org/ 10.1016/j.jclepro.2017.03.180

Original publication available at:

https:// doi.org/ 10.1016/j.jclepro.2017.03.180

Copyright: Elsevier

http:// www.elsevier.com/

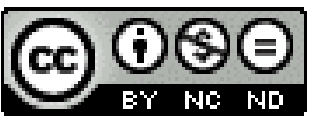




\title{
The role of biogas solutions in sustainable biorefineries
}

\author{
Linda Hagman $^{\mathrm{a}, *}$, Alyssa Blumenthal ${ }^{\mathrm{a}}$, Mats Eklund ${ }^{\mathrm{a}}$, Niclas Svensson ${ }^{\mathrm{a}}$ \\ ${ }^{a}$ Environmental Technology and Management, Linköping University, SE-581 83 Linköping, \\ Sweden \\ * E-mail address: linda.hagman@liu.se
}

\begin{abstract}
Biorefineries strive to maximise product mix and value while contributing to the bioeconomy. Circularity and waste valorisation are some important but often neglected concepts in this context. As such, biogas solutions in biorefineries could be a key technology to improve sustainability. This study has, through a literature review and investigation into three Swedish case studies, analysed this relationship between biogas solutions and biorefineries by assessing the added value and development potential to which biogas solutions may contribute. This analysis across agricultural, forest, and marine sectors indicates that biogas solutions contribute with several added values, including through making the biorefinery more sustainable and competitive. The study also shows that biogas solutions can be an enabler of biorefinery development through making the system more resilient and versatile, as well as through improving the value of the product portfolio.
\end{abstract}

\section{Keywords}

Biorefinery; Biogas; Bioeconomy; Valorization; Anaerobic digestion; Waste management

\section{Introduction}

Biorefining, as per the International Energy Agency (IEA), is the "sustainable processing of biomass into a spectrum of marketable products (food, feed, materials and chemicals) and energy (fuels, power, heat)" (Sonnenberg et al., 2007, p. 2). It is also a concept growing in prominence and importance, driven by industry needs for business development and resource efficiency, as well as policies promoting the sustainable use of biomass. In particular, biorefineries are believed to play an important role in the move towards a bioeconomy, in which renewable and biobased materials replace fossil products (Sauvée and Viaggi, 2016). Biorefinery development could consist of dynamically growing networks of already existing industries rather than building completely new biorefinery complexes (Ersson et al., 2015). Already in the European Union (EU) today it is increasingly common for biofuel industries to diversify into biorefineries (de Jong et al., 2013). However, to live up to their potential, it is important that biorefineries have an energy recovery step in their processes (Wagemann, 2012). As sustainability performance of a biorefinery is heavily linked to product portfolio and the minimisation of waste generation, this energy recovery step, as well as any possible end-of-stream material recovery and reuse, becomes important to consider in relation to biorefinery success and development.

In this regard, biogas solutions can contribute to better sustainability performance of a biorefinery, as biogas solutions enable the conversion of biomass into energy carriers and digestate through the anaerobic digestion (AD) process. Energy carriers can be used for heat and electricity, for vehicle fuel, or for substituting natural gas in a gas grid. Digestate can be used as a biofertiliser, allowing for nutrient recovery and subsequently, a potential increase in feedstock production in either agricultural or forest activities (Langeveld et al., 2010). 
This enables upcycling in the biorefinery system, in which lower valued biomass moves to higher values (Martin and Parsapour, 2012). This stands in contrast to the traditional cascading pyramid representation of the biorefinery, where for each step in the production process, value decreases and volume increases (Langeveld et al., 2012). Whereas the traditional model only allows for single, downward directionality, incorporating upcycling into this representation allows for the possibility of bi-directionality. As such, this provides a framework for understanding how processes like biogas solutions contribute value and support the biorefinery system's business, leading to further development of the biorefinery (Figure 1).

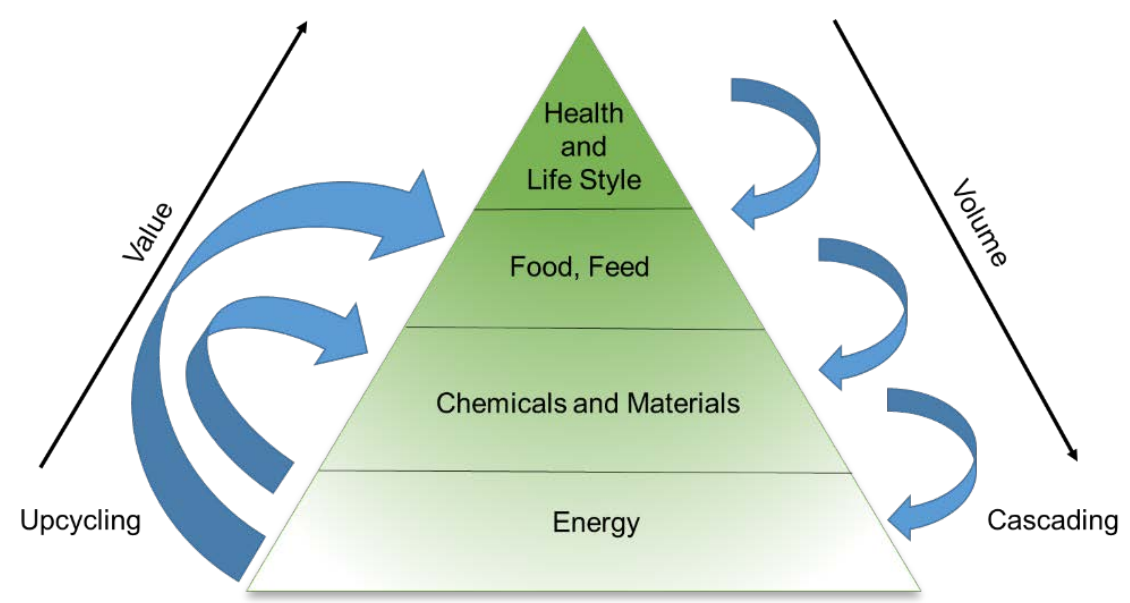

Figure 1. Cascading and upcycling in the biorefinery product pyramid.

This framework also can be used to consider the possible drawbacks to the anaerobic digestion process. Depending on raw material and upgrading technology, biogas quality may be insufficient for replacing natural gas (Eriksson, 2010). Instable digestion may also result in an unreliable gas supply, again preventing fuel substitution and minimising value (Wang et al., 2011). In areas where biogas solutions exist far from a market, storage and logistics may also impact the upcycling and valorisation potential of this product. However, maximising internal biogas use, as well as promoting use of other anaerobic digestion products like digestate may ease this concern. Of course, digestate quality can also be a limiting factor in its application, but as biorefineries mainly use pure and well-defined raw materials, this problem can frequently be handled through conventional quality control mechanisms (Al Seadi and Lukehurst, 2012).

While other energy recovery solutions, such as incineration in a combined heat and power (CHP) plant, may make more sense when handling certain wastes, particularly those with lesser moisture content, an analysis of the function of different waste treatment methods by Mountraki et al. (2016) suggests that biogas solutions are the most versatile method. This is due to their ability to handle substrates with various dry solid matter content, biochemical oxygen demand (BOD), chemical oxygen demand (COD) and nutrient values as well as their cost efficiency which is stressed by the authors (Mountraki et al., 2016). For these reasons, as well as the combined waste treatment and energy recovery abilities of biogas solutions, coupled with their capacity to generate new products in the form of biogas and digestate, biogas solutions are interesting to assess from a biorefinery perspective. Furthermore, while previous articles have discussed biorefineries using biogas production as a treatment, the role which biogas solutions play in a biorefinery's development potential has seldom been explored. 
To this end, we have sought to analyse and clarify the role of biogas solutions in biorefinery settings in order to understand how they influence value creation. In doing so, we strive to provide insight into the following research questions: (1) how are biogas solutions characterised within biorefinery settings, (2) what are their contributions to sustainability, and

(3) in what ways do these solutions have a potential impact on the growth and development of biorefineries?

\section{Methodology}

This work is based upon a literature study during 2016 as well as interviews with key persons from three Swedish biorefinery settings. The studied cases represent the agricultural, forest and marine sectors. Through this, the study captures each of the three residue-based biorefinery types as classified by the International Energy Agency (IEA) Bioenergy Task 42. IEA Bioenergy identifies organic, oil-based, and lignocellulosic processing residues - from agricultural, marine and forest sectors, respectively - as the dominant secondary feedstocks for biorefineries (Cherubini et al., 2009).

\subsection{Literature study}

An initial scientific literature search focused on waste management in biorefineries was performed to assess how waste streams are generally handled in existing and planned biorefineries. This yielded approximately 500 hits. A secondary search then narrowed the focus to anaerobic digestion in biorefineries to gain more insight into this particular treatment. Keywords used in this search included biorefin*, waste, waste management, waste treatment, biogas, anaerobic digestion, and sustainab*, in combination with sector-specific keywords like forest, pulp and paper, agricultur*, biofuel, marine, algae, and fish industry. Additional articles already known to the researchers were included in the review, and articles found discussing cases where waste was the designated feedstock of a biorefinery were excluded, as the interest of this study is in those biorefineries using non-waste initial feedstocks. Thirty references were identified for further review and analysis.

Within this final literature body, discussions of added value or sustainable development potential attributed to biogas solutions in the biorefineries they serve were of particular interest. In this way, the literature study was used to identify general trends regarding the handling of "waste" streams and by-products in biorefinery concepts, as well as to better understand to what extent biogas solutions are used. We thus do not compare different waste treatments in this article, but rather identify added values when biogas solutions are integrated. The literature study therefore contributes largely to our first two research questions: (1) the characterisation of biogas solutions in biorefineries, and (2) their contribution to sustainability performance.

\subsection{Case studies}

The goal of these case studies was to contribute practical understanding of biorefineries, planned or operational, and to understand the role of biogas solutions in a few settings across sectors. The chosen cases were in different phases of development and have different incentives to implement anaerobic digestion. The case studies were based on production facilities and contexts where earlier studies have been performed. Thus, the cases were quite familiar to the authors of this paper.

Our study of these contexts was performed through semi-structured interviews with representatives of key companies involved in the biorefinery settings, with specific questions 
posed regarding the integration and role of anaerobic digestion at their respective facility. Interview questions and their order were the same for all actors, but follow up questions were asked as deemed fitting throughout each interview. Each interviewee received the questions prior to the interview to be able to prepare. All interviews were held over the phone and recorded. The interviewers gathered information regarding the historical development, role of biogas solutions, and decision-making processes inherent to each biorefinery setting. Additionally, interviewees were asked whether they could identify any specific added value from their system-specific biogas solutions, and whether they could see any development potential attributed to these solutions. The case studies will therefore contribute to all three of the research questions.

Three main informants, one for each sector, were selected based on their overall operational knowledge. In the agricultural case, the CEO of the main supplier of biorefinery substrate was selected for interview. This was due to his knowledge of the biorefinery's biogas plant, and the fact that his company's development heavily influences the conditions for this plant. The forest case informant serves as a development engineer and is knowledgeable about the operational aspects of the whole biorefinery as well as the AD system. The informant representing the marine case is a partial owner of an intermediary company in charge of a planned biogas plant, which when constructed, will serve several fish processing industries. He previously worked for one of these fish processing industries and thus has extensive knowledge about the involved companies as well as more high-level knowledge about the future biorefinery development.

The selection of interviewees was informed by earlier contacts and studies. However, we acknowledge that other representatives of their companies, or representatives from other parties involved in the various biorefinery cases, may have different views. As such, every effort was made to use published company-level literature to further contribute to our understanding of each of these biorefinery settings. Also, earlier studies made the empirical material richer and more diverse. For instance, a previous interview with the individual mediating between the wheat processing plant and the biogas plant in the agricultural case served as useful secondary material, as did information from another company distributing biofertiliser from the biogas plant.

\subsection{Analysis method}

Results from the literature and case studies were collected and organised using a matrix, allowing for the sorting of findings based upon source (i.e., literature or case study) and research question in focus (i.e., characterisation of biogas solutions). In doing so, similarities and differences between the literature and cases, and among the cases themselves, were more easily identifiable. The most interesting aspects were then brought up for discussion.

\section{Results}

\subsection{Literature review}

\section{Agriculture}

Biogas solutions as part of biorefineries in the agricultural sector are often connected with biofuel industries such as bioethanol or biodiesel (Bateni et al., 2014; Martin, 2013; Wilkie et al., 2000; Wood et al., 2013). In these cases, biofuels are typically produced from crops such as wheat, maize, or rapeseed. There are also examples of more small-scale agricultural 
applications for biogas solutions based on manure and agricultural residues, but they are seldom in large industrial scale (Oleskowicz-Popiel et al., 2012).

Biogas solutions as waste treatment can reduce chemical oxygen demand (COD) in thin stillage from ethanol plants and other organic wastewater streams (Wilkie et al., 2000). Generating methane while reducing COD and replacing natural gas with biogas are useful sustainability measures (Schmidt et al., 2013; Wood et al., 2013). External energy demand can also be reduced when wet substrates with more than $80 \%$ water content are digested anaerobically making the process more efficient (McKendry, 2002).

Substrates from crops, manure, or industrial by-products can be used for $\mathrm{AD}$, and the produced digestate re-circulated on agricultural fields as biofertiliser and soil conditioner (Bauer et al., 2007). Biogas solutions thereby represent a way to use agricultural crops and residues more sustainably while closing loops. Aerobic treatments are not as useful in this context as the sludge produced requires further treatment before it can be used as fertiliser or incinerated (Henze, 2008). The circularity of AD, then, can improve resource efficiency as well as generate higher valued products rather than waste (Pfaltzgraff et al., 2013). Fertiliser needs in agriculture have increased in past decades and the availability of mineral phosphorous is decreasing rapidly, urging a solution for future nutrient needs (Ridder, 2012). Furthermore, with renewable nutrients and energy as inputs for the biorefinery production system, carbon footprints can be reduced, as well as dependence on fossil resources. Biogas can be used internally as an energy carrier at a biorefinery to meet this end (Bauer et al., 2007).

Looking at social and economic value from biogas solutions in these agricultural biorefineries, arguments have been made that these solutions satisfy cleaner production demands from customers, create employment opportunities, and improve company image, both in the food and chemical industry (Pfaltzgraff et al., 2013). However, this development is hindered by several challenges, like the need for improved pre-treatment if, for example, straw is being considered as an AD substrate (Costa et al., 2013).

\section{Forest}

Within the forest sector, advanced biorefineries have been gaining momentum, particularly among the pulp and paper (P\&P) industry, where pre-existing infrastructure - facilities for thermochemically converting wood inputs into both material and energy products - can be considered an enabler for more advanced biorefinery development (Huang et al., 2011). Additionally, forest and mill residues are considered to be among the most promising woodbased biomass sources for such biorefinery development (Näyhä and Horn, 2012). The most common current use for these residues within forest biorefineries is Fischer-Tropsch diesel, which allows for upcycling via gasification (Näyhä and Horn, 2012). This method does not capture the benefits of the digestate though, as ashes lack the carbon source, nitrogen and microorganisms available in digestate-based biofertiliser (García-Sánchez et al., 2015).

Anaerobic digestion (AD) also has increasingly been included in forest-based biorefineries, where it may play a variety of roles. Frequently, AD is viewed as an energy solution, with methane production serving as a revenue stream, or with generated sludge enabling heat and electricity production (Joelsson et al., 2015; Lee et al., 2014; Lin et al., 2013). In such discussions, AD may be viewed as one of many biofuel production options, but one which also leads to more efficient wastewater treatment operation. This increased efficiency can be achieved, for example, through wastewater recovery and system energy cost reduction (Berni 
et al., 2014; Sharma et al., 2015). There are of course cases where the biorefinery is nonprofitable but it seem to depend on what products are produced and what selling price is set on the products (Nitzsche et al., 2016).

In reviews of P\&P wastewater treatment methods, anaerobic digestion has continuously and consistently been discussed as a viable biological process with advantages over conventional aerobic treatment techniques. Such advantages include sludge volume reduction, lower chemical consumption, and operational simplicity, as well as simultaneous energy production and savings (Kamali and Khodaparast, 2015; Thompson et al., 2001). Also, economic comparisons suggest that anaerobic treatments are preferable when there is the possibility for internal use of the gas produced, if soil conditions are poor for aerobic treatments, if the temperature of the substrate is high (meaning less cooling is required) or if there is a lack of land to implement aerated treatments (Rantala and Väänänen, 1985). Furthermore, waste treatment via $\mathrm{AD}$ also enables the production of soil conditioner or biofertiliser from digestate (Berni et al., 2014; González-García et al., 2011; Meyer and Edwards, 2014).

Additionally, interesting connections are apparent between AD inclusion in forest-based biorefineries and the extension of biorefinery feedstocks. In particular, the ability to use digestate from $\mathrm{AD}$ as a source for microalgae growth, and subsequent harvesting of high value algal lipids, poses a unique development possibility (Kouhia et al., 2015; Polishchuk et al., 2015). In several instances, the forest-based biorefinery literature also highlights that the presence of an $\mathrm{AD}$ system opens new opportunities for expanding waste sources and streams for co-digestion (Chinnaraj et al., 2011; Kemppainen et al., 2012). In regards to biorefinery expansion, anaerobic digestion's ability to stabilise sludge is also discussed as an opportunity for further sludge-based refining, and more generally as a method for diversification of P\&P mills. As such, AD can be viewed as an enabler for entry into new markets (Bayr et al., 2013; Greenbaum, 2005; Kamali and Khodaparast, 2015). In moving towards a circular bioeconomy, AD's role in generating value from residues is also seen as an important step towards the complete utilisation of feedstock and towards waste reduction (Kemppainen et al., 2012).

\section{Marine}

The literature regarding marine biorefineries and biogas solutions is mainly focused on algal biomass and in particular microalgae (Andersson et al., 2014; Barbot et al., 2015; Bravo-Fritz et al., 2016; Collet et al., 2011; Mussgnug et al., 2010). Algae is versatile as it can be used for extraction of proteins, polysaccharides, pigments, minerals and other products (Cardoso et al., 2014). In algal biorefineries, heat and power can be produced and digestate recirculated to the algae farm. Carbon dioxide $\left(\mathrm{CO}_{2}\right)$ may also be extracted from the raw gas for use in algae growth (Collet et al., 2011). It is important to extract high value products before letting waste be used for energy purposes, but synergistic effects regarding value creation and waste management can be revealed when biorefinery concepts are developed (Mussgnug et al., 2010). Algae production in combination with biogas solutions is a promising match in this regard as $\mathrm{AD}$ can contribute nutrients and carbon dioxide, which are required for growing algae (Costa et al., 2013).

Studies also suggest that algal bioenergy is going to expand in the future (Costa et al., 2013). Algal-based industries will therefore start moving towards a diverse range of products from algal biomass (Cardoso et al., 2014). Using algal biomass for such bioenergy and biomaterial production, as compared with land-based biomass, offers several benefits to a biorefinery with biogas solutions. There is no competition with food crops for the land or fresh water resources 
(Daroch et al., 2013). There are also potentially higher biogas yields related to algal feedstocks than to many other AD feedstock options, during optimal conditions algae has almost five time higher methane yields than maize (Murphy et al., 2015). Additionally, studies suggest that marine biorefineries can reduce costs, increase their efficiency and competitiveness within the industry, as well as improve flexibility in their product mix (Vanegas Ramirez, 2015; Langlois et al., 2012).

Marine biorefinery concepts have been less studied among the fish industry, but methane potential from fish waste has been assessed several times as having a high development potential (Kafle et al., 2013; Mshandete et al., 2004; Navickas et al., 2013). Additionally, new regulations in the European Union regarding unwanted catch favour the development of biorefineries and biogas solutions. These regulations prevent throwing fish back to sea, and also limit their use for human consumption (Weissenberger, 2013). This opens new opportunities for fodder or biogas production. However, biogas solutions are not a common waste treatment in the fish industry since fish waste is more commonly upcycled to fodder or oils (Antelo et al., 2015). What is left after these processes, though, could be treated by AD and again upcycled to more valuable products rather than sending the biomass for incineration or landfilling (Antelo et al., 2015). Biogas solutions are useful for wet substrates especially and development within this sector shows great potential (McKendry, 2002). The wet substrates are also a possible drawback if distances become too long as the cost for transportation increases (Bravo-Fritz et al., 2016).

\subsection{Case studies}

As discussed in Chapter 2, our analysis of biorefinery contexts was concentrated within the residue-based biorefinery settings as profiled by IEA Bioenergy Task 42 . While the biorefineries profiled in our case studies are not exclusively residue-based, the anaerobic digestion system in focus relies on residues in each context. Therefore, we have classified each of the cases in both primary and secondary feedstock settings (Figure 2).

\section{Agriculture}

The agricultural case consists mainly of a potable ethanol producer, a CHP plant and a biogas plant with anaerobic digestion. The ethanol plant started its business in the 1980s, and its substrate deliveries to the biogas plant started in 2012. The ethanol plant does not only produce potable ethanol but also starch, syrup, gluten for industry, and fodder, with a systemwide goal of increasing the value from wheat as an input. The by-product, stillage, which today is digested in the biogas plant, is the same by-product used as fodder. Thus, this byproduct is upcycled via two different techniques in this biorefinery setting.

The biogas plant is situated $3 \mathrm{~km}$ away from the ethanol producer and is owned by a different company. The stillage from the ethanol plant is co-digested with food waste from other industries in the area, as well as with some agricultural residues. According to IEA's classification system, this case is classified as a three-platform (C5 sugar, C6 sugar, and biogas) biorefinery for the production of biomethane, fertiliser, animal feed, food, and bioethanol from starch crops (see Figure 2a). The AD system can be viewed as a one-platform (biogas) biorefinery for biomethane and fertiliser production. The largest product volumes are ethanol and stillage, while starch and gluten are the highest valued products. 
Produced biogas is upgraded and used as vehicle fuel, while digestate is sold and used by farmers in the region. The relationships between the actors build on conventional business agreements and these actors do not define or brand themselves as a biorefinery network. The ethanol plant benefits from this relationship mainly through income from the biogas plant in return for the substrate they provide. This business agreement also has solved a problem for the ethanol plant as the fodder market is saturated and expanding that market is not possible at the moment. One additional effect of the biogas solution in this setting is that it has enabled more organic farming in the region.

Development of this system is driven by economic reasons. The ethanol plant needs the biogas plant to expand its production since fodder markets are limiting. The biogas plant also depends on income from sales of biomethane and biofertiliser, which substrate from the ethanol plant enables. Having both fodder and biogas possibilities available increase the resilience of the biorefinery production system and the flexibility of the individual actors. In the future, the fodder market might be further developed, enabling increased fodder production and potentially less need for a biogas plant. However, having two different markets for stillage will continue to provide value and security for the ethanol producer. 


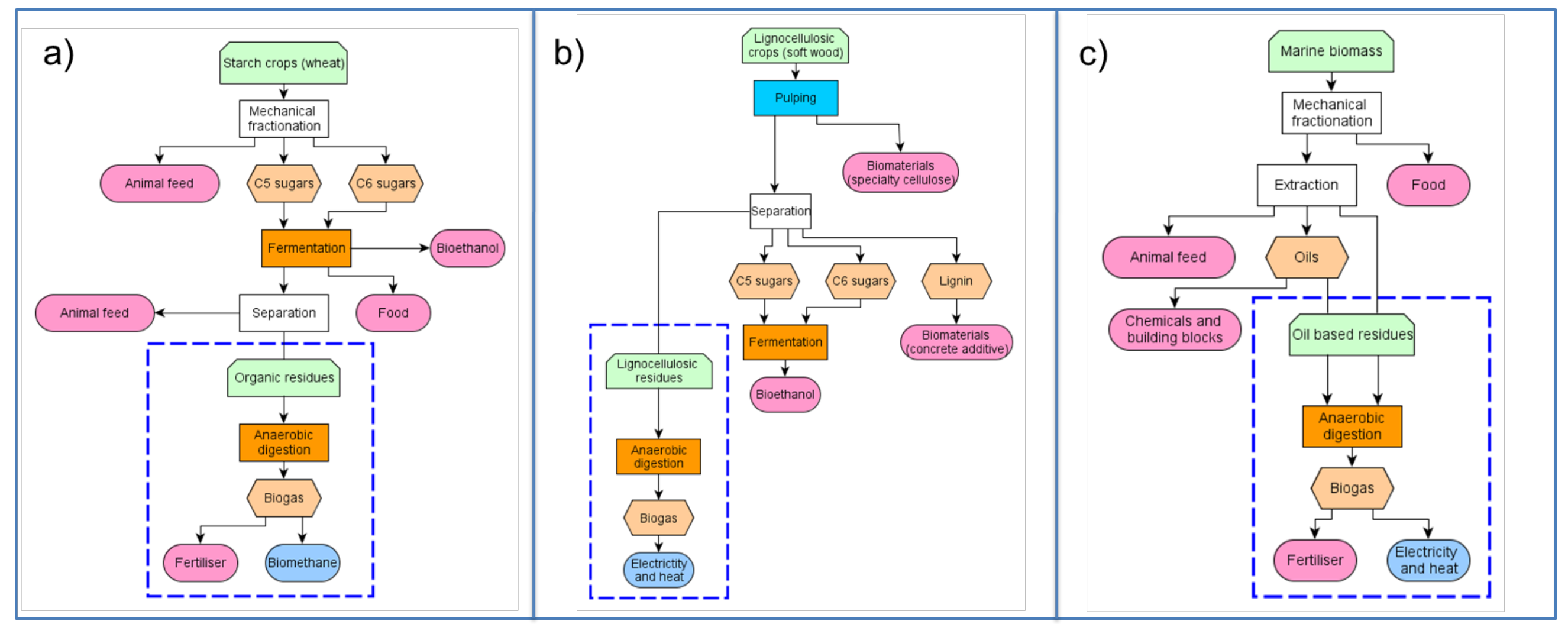

Figure 2. System diagrams for the biorefinery settings studied according to the IEA’s biorefinery classification system. (a) Agricultural case:

Classified as a three-platform (C5 sugar, C6 sugar, and biogas) biorefinery for biomethane, fertiliser, animal feed, food, and bioethanol from starch crops. Zooming in on the organic residue portion of this biorefinery (see dotted blue border), the AD system can be viewed as a one-platform (biogas) biorefinery for biomethane and fertiliser. (b) Forest case: Classified as a four-platform (lignin, C5 sugar, C6 sugar, and biogas) biorefinery for electricity and heat, bioethanol, and biomaterials from lignocellulosic crops. Zooming in on the residues from the lignocellulosic processing portion of this biorefinery, the AD system can be viewed as a one-platform (biogas) biorefinery for electricity and heat. (c) Marine case: Classified as a twoplatform (oils and biogas) biorefinery for electricity and heat, fertiliser, animal feed, chemicals and building blocks, and food from marine biomass. Zooming in on the oil based residue portion of this biorefinery, the AD system can be viewed as a one-platform (biogas) biorefinery for biomethane and fertiliser. 


\section{Forest}

The second biorefinery network studied exists within the pulp and paper industry and is located in northeast Sweden. This once traditional sulphite pulp mill now operates as a diverse biorefinery producing dissolving grade speciality cellulose, bioethanol, and lignin for use as dispersant in concrete. Biogas is also produced at the facility and used predominantly internally for the drying of lignin and for the generation of electricity and steam. Some steam is also used for district heating in the neighbourhood. Several other industrial companies act in this area and are also involved with further refining of forest residues, as well as the contribution of lesser volume waste streams to the mill's anaerobic digestion (AD) system. Within the IEA biorefinery framework, this system can be classified as a four-platform (lignin, C5 sugar, C6 sugar, and biogas) biorefinery for electricity and heat, bioethanol, and biomaterials from lignocellulosic crops (see Figure 2b). Zooming in on the residues from the lignocellulosic processing portion of this biorefinery, the AD system can be viewed as a one-platform (biogas) biorefinery for electricity and heat. The largest volume and highest value product generated in this system is specialty cellulose.

Anaerobic digestion in this community was initially built in 1985 for water cleaning purposes, specifically for the degradation of COD. No pre-treatment of substrate or post-treatment of digestate is required. Digestate sufficiently meets environmental regulations and is released directly into a receiving river. AD was selected as the waste treatment technology of choice due to its treatment efficiency coupled with its ability to generate an upcycled product from waste streams in the form of biogas. The addition of $\mathrm{AD}$ also enabled the biorefinery to increase production capacity, close their bleaching loop, and eliminate process water discharge into the neighbouring water body.

Within this forest biorefinery, proper operation of the anaerobic biotreatment plant is vital. If the AD stands still, the biorefinery suffer a great economic loss, on the magnitude of 100,000 SEK per day. The biogas plant is therefore crucial for the biorefinery's production. The gas replaces liquefied natural gas or light oil to feed their lignin driers, and this contributes to the mill's sustainability profile and decreases dependence on fossil energy. Anaerobic digestion has also become an important part of the biorefinery's environmental profile. The existence of this biotreatment plant has allowed for fish repopulation in the mill's neighbouring water body where once this river was uninhabitable. Furthermore, AD works as a tool for fulfilling the mill's mission to "make as much value out of the tree as possible."

The existence of $\mathrm{AD}$ at the forest biorefinery continues to enable growth and increased valorisation of new products. Currently, a soil improver is being developed using post-digestion sludge and other on-site residues, such as those from debarking, as primary components.

\section{Marine}

In the marine biorefinery case, actors are developing a biogas plant close to a large, existing fish processing industrial complex. This biogas plant will handle the industries' waste and wastewater. Three large companies producing a variety of fish for human consumption are located in the existing complex. They have been active in the area for decades. At present, large amounts of sludge and fish waste are transported to distant biogas plants and fodder producers 
for further treatment. In addition to the aforementioned waste streams, another input to the biogas plant will be unwanted catch from fishermen and expired fish from vendors.

The intermediary company planning the biogas plant is also involved in developing new product streams from waste and by-products in addition to the typical biogas and digestate. This plan includes the development of land-based fish and algae farming, with the goal of ultimately establishing a marine biorefinery. This development involves both cascading and upcycling as waste flows will be used for extraction of valuable products, such as special oils, vitamins, proteins, and enzymes after food is produced. According to the IEA classification (see Figure 2c) this case is a two-platform (oils and biogas) biorefinery for electricity and heat, fertiliser, animal feed, chemicals and building blocks, as well as for food from marine biomass. Animal feed and oils for digestion are produced in the largest volumes, but the most value lies in the food products and chemicals. Zooming in on the oil based residue portion of this biorefinery, the AD system can be viewed as a one-platform (biogas) biorefinery for biomethane and fertiliser.

In this planned biorefinery network, heat and power will be used internally by the companies within the network. Specifically, the heat will be used for fish and algae tanks for climate control. The electricity will be used in the large refrigerated storage facilities needed by the fish producers. The biogas plant intends to certify its digestate as biofertiliser for organic farming and sell it to farmers in the nearby region.

Perhaps one of the most important aspects of the anaerobic digester will be the treatment of the water from the production processes. Today, there is pollution and eutrophication from the fish industries, but with $\mathrm{AD}$, this will be reduced and become much cleaner when discharged to the sea. Another aspect emphasised by actors in the network is the role of $\mathrm{AD}$ in the solving of an infrastructure problem. Currently, extensive truck transport is required for these industries to dispose of their by-products and sludge at distant facilities. By having a biogas plant nearby, the companies can deliver these by-products there instead and reduce emissions and other unwanted impacts from trucks. This environmental benefit will also enable the companies in this network to use their biorefinery and biogas strategy for branding purposes. Reducing transports will also reduce costs. With these efficient infrastructure solutions, company owners are less likely to move production to other sites. So, the whole development holds the potential to make the involved companies more competitive. There is therefore a possibility for expansion of production and employment in the network's facilities.

In this way, the establishment of a biogas plant to treat fish waste seems to enable and trigger progress towards developing a marine biorefinery. The intermediary company has disseminated a vision of extracting as much value from the substrates as possible, which has attracted the interest of new companies to establish in the area. The biogas plant has further encouraged the involved companies to view their processes in a circular system, therefore making them more eager to identify opportunities for more value extraction.

\subsection{Synthesis}

In Table 1, the results from each sector are compiled in connection to our research questions. Many similarities regarding economic values and internal uses of the energy become apparent, but so do differences regarding valorisation and efficiency within these biorefinery settings. 
Table 1. Results from case studies and literature review shown regarding the characterisation, contribution and potential of biogas solutions in biorefineries.

\begin{tabular}{|c|c|c|c|c|c|c|}
\hline & $\begin{array}{l}\text { Case: } \\
\text { Agriculture }\end{array}$ & $\begin{array}{l}\text { Literature: } \\
\text { Agriculture }\end{array}$ & Case: Forest & $\begin{array}{l}\text { Literature: } \\
\text { Forest }\end{array}$ & Case: Marine & $\begin{array}{l}\text { Literature: } \\
\text { Marine }\end{array}$ \\
\hline $\begin{array}{l}\text { RQ1. } \\
\text { Characterisation of } \\
\text { biogas solutions }\end{array}$ & $\begin{array}{l}\text { Biogas: } \\
\text { Vehicle fuel } \\
\text { Digestate: } \\
\text { Biofertiliser } \\
\text { (certified } \\
\text { organic) }\end{array}$ & $\begin{array}{l}\text { Biogas: } \\
\text { Replace } \\
\text { natural gas } \\
\text { Digestate: } \\
\text { Biofertiliser } \\
\\
\text { Other: } \\
\text { Wastewater } \\
\text { treatment }\end{array}$ & $\begin{array}{l}\text { Biogas: Heat } \\
\text { and power } \\
\text { (internally)/ } \\
\text { replace } \\
\text { natural gas } \\
\text { Digestate: } \\
\text { Discharged } \\
\\
\text { Other: } \\
\text { Wastewater } \\
\text { treatment }\end{array}$ & $\begin{array}{l}\text { Digestate: } \\
\text { Biofertiliser } \\
\text { Other: } \\
\text { Wastewater } \\
\text { treatment }\end{array}$ & $\begin{array}{l}\text { Digestate: } \\
\text { Biofertiliser } \\
\text { (certified } \\
\text { organic) } \\
\text { Other: } \\
\text { Wastewater } \\
\text { treatment }\end{array}$ & $\begin{array}{l}\text { Digestate: } \\
\text { Nutrients used in } \\
\text { algae farms } \\
\text { Other: Waste } \\
\text { management; } \\
\mathrm{CO}_{2} \text { extraction }\end{array}$ \\
\hline $\begin{array}{l}\text { RQ2. } \\
\text { Contribution of } \\
\text { biogas solutions to } \\
\text { sustainability }\end{array}$ & $\begin{array}{l}\text { Economic } \\
\text { value } \\
\text { Organic } \\
\text { farming. }\end{array}$ & $\begin{array}{l}\text { Reduce COD } \\
\begin{array}{l}\text { Decrease } \\
\text { drying needs }\end{array} \\
\text { Increase } \\
\text { employment }\end{array}$ & $\begin{array}{l}\begin{array}{l}\text { Decrease } \\
\text { water } \\
\text { pollution }\end{array} \\
\text { Increase } \\
\text { production } \\
\text { Enable } \\
\text { efficient } \\
\text { process } \\
\text { changes }\end{array}$ & $\begin{array}{l}\text { Reduce } \\
\text { energy cost } \\
\text { Reduce } \\
\text { sludge } \\
\text { volume } \\
\text { Decrease } \\
\text { needed } \\
\text { chemicals }\end{array}$ & $\begin{array}{l}\text { Improve } \\
\text { infrastructure } \\
\text { Waste } \\
\text { treatment } \\
\text { Decrease } \\
\text { transportation } \\
\text { need }\end{array}$ & $\begin{array}{l}\text { Reduce costs } \\
\text { Solve a fish waste } \\
\text { problem } \\
\text { Limit competition } \\
\text { with food crops } \\
\text { and fresh water } \\
\text { use }\end{array}$ \\
\hline $\begin{array}{l}\text { RQ3. } \\
\text { Potential of biogas } \\
\text { solutions to } \\
\text { influence biorefinery } \\
\text { growth and } \\
\text { development. }\end{array}$ & $\begin{array}{l}\text { Expand } \\
\text { production for } \\
\text { ethanol plant }\end{array}$ & $\begin{array}{l}\text { Using wet } \\
\text { substrates } \\
\text { and straw- } \\
\text { like } \\
\text { substrates } \\
\text { Satisfy } \\
\text { customers } \\
\text { Enhance } \\
\text { company } \\
\text { image }\end{array}$ & $\begin{array}{l}\text { Increase } \\
\text { production } \\
\text { Product } \\
\text { valorisation } \\
\text { Contribute to } \\
\text { improved } \\
\text { image } \\
\text { Marketing }\end{array}$ & $\begin{array}{l}\text { Product } \\
\text { valorisation } \\
\text { Entrance } \\
\text { into new } \\
\text { market } \\
\text { Enable } \\
\text { simple } \\
\text { operation } \\
\text { Diversify } \\
\text { product } \\
\text { portfolio }\end{array}$ & $\begin{array}{l}\text { Attract new } \\
\text { companies to } \\
\text { expand the } \\
\text { biorefinery } \\
\text { Product } \\
\text { valorisation } \\
\text { Marketing }\end{array}$ & $\begin{array}{l}\text { Increase } \\
\text { efficiency of the } \\
\text { industry } \\
\text { Promote } \\
\text { competitiveness } \\
\text { Increase product } \\
\text { flexibility }\end{array}$ \\
\hline
\end{tabular}

\section{Discussion}

In this section, we will highlight and expand upon our main observations and findings as outlined in Table 1. To start, there is a wide range of uses of anaerobic digestion in biorefineries, ranging from common heat and power applications to less conventional carbon dioxide extraction methods. In this way, the positive impacts attributed to these solutions are far-reaching and diverse. Overarchingly though, biorefinery management seems to treat biogas solutions as a part 
of their refinery rather than as a separate waste management component, which often is the case for aerobic treatments and incineration facilities.

Another discussion point to highlight is the relevance for producers, entrepreneurs, farmers, fishers and foresters to develop biorefinery networks for the transition towards a sustainable bioeconomy. Biogas solutions can offer a convenient energy infrastructure and a waste treatment method that is useful across industrial sectors that, through upcycling potential, may make them more competitive. Increased competitiveness may also be achieved through sustainability and resource-efficiency branding. Still, biorefinery concepts can develop through conventional business development without the actors using this specific terminology, as in the agricultural case studied. However, our work suggests that companies identifying themselves as biorefinery networks may more actively strive for further valorisation and diversification of products finding new substrate streams to use in anaerobic digestion, identifying added value and involving neighbouring industries and communities in their efforts, as in the illustrated forest and marine cases.

On the topic of biorefinery growth and development, the potential of biogas solutions in product valorisation are important in all studied sectors, although different terminology may be used in describing this valorisation (see RQ3 in Table 1). Combining biogas solutions and other biomass industries should also be explored as a way to improve overall performance, in contrast with independently functioning industry players (Börjesson et al., 2013; Martin, 2013, 2010). As biorefinery concepts are built on the ambition of creating as much value as possible from their raw material, we propose that biogas solutions should be viewed as an enabler for the biorefinery to start up and develop its production. When biorefineries can invest in new technologies leading to new products, they increase the value of their raw material while reducing the amount of substrate being eliminated at the end of the production process. Such enabling of product valorisation should be promoted and marketed in a suitable way since it contributes to a broader product portfolio and the company becomes more resilient to changes in the market (Langlois et al., 2012). Biorefineries with biogas solutions, then, are more dynamic systems where new feedstocks and industrial actors can be introduced to existing ones, and where changing market conditions need not herald distress (Ersson et al., 2015).

Finally, another aspect to discuss, and one which is worthy of further investigation, is the alternative costs of not having a biogas solution within a technically suitable biorefinery. Reduced cost and economic value are frequently discussed, in the literature and in our cases, when discussing AD in biorefineries (see RQ2 in Table 1). These reduced costs are specifically connected to alternative treatment methods, energy sources, and revenue streams which can be replaced through AD incorporation. Most biorefineries require some kind of water treatment, and it has been argued that choosing an aerobic process will not be more economically viable than anaerobic treatment (Rantala and Väänänen, 1985). Furthermore, with anaerobic digestion, the biorefinery also has the opportunity to become more energetically self-sufficient, either through replacing natural gas or through heat and power generation. The economics of an AD system can be improved with an integrated biorefinery producing high value products and internal energy, yet more research is warranted to model and assess the economic trade-offs within a diverse range of biorefinery systems (Suominen et al., 2014). 


\section{Conclusions}

Biogas solutions are characterised by several possible uses of the treatment itself and of its products. Economically, the most easily identifiable contributions from biogas solutions are reduced and avoided energy and waste treatment costs. However our research suggests that the most interesting, and more impactful, contribution of these solutions lies in their potential for product valorisation and material upcycling. In biorefinery settings, new processes and products are constantly being evaluated for increased production opportunity and profitability, and this driver consistently motivates players across our cases studies. Further research will be required to determine whether this holds true for biorefineries outside the Swedish setting, but our research suggests that biogas solutions for wastewater treatment and energy conversion in biorefineries have the potential to enable business development while increasing competitiveness, product portfolio, and sustainability of these systems. Such biogas solutions can also lead to better resilience towards changes in the market and are suitable in periods of transition and development while new products from waste streams are developed.

\section{Acknowledgement}

This research has been funded by the Biogas Research Center (BRC), which is in turn funded by the Swedish Energy Agency. We would also like to thank the anonymous reviewers for their valuable input and comments. 


\section{References}

Al Seadi, T., Lukehurst, C., 2012. Quality management of digestate from biogas plants used as fertiliser, in: IEA Bioenergy, Task 37.

Andersson, V., Broberg Viklund, S., Hackl, R., Karlsson, M., Berntsson, T., 2014. Algae-based biofuel production as part of an industrial cluster. Biomass Bioenergy 71, 113-124. doi:10.1016/j.biombioe.2014.10.019

Antelo, L.T., de Hijas-Liste, G.M., Franco-Uría, A., Alonso, A.A., Pérez-Martín, R.I., 2015. Optimisation of processing routes for a marine biorefinery. J. Clean. Prod. 104, 489-501. doi:10.1016/j.jclepro.2015.04.105

Barbot, Y.N., Thomsen, L., Benz, R., 2015. Thermo-Acidic Pretreatment of Beach Macroalgae from Rügen to Optimize Biomethane Production-Double Benefit with Simultaneous Bioenergy Production and Improvement of Local Beach and Waste Management. Mar. Drugs 13, 56815705. doi:10.3390/md13095681

Bateni, H., Karimi, K., Zamani, A., Benakashani, F., 2014. Castor plant for biodiesel, biogas, and ethanol production with a biorefinery processing perspective. Appl. Energy 136, 14-22. doi:10.1016/j.apenergy.2014.09.005

Bauer, A., Hrbek, R., Amon, B., Kryvoruchko, V., Bodiroza, V., Wagentristl, H., Zollitsch, W., Liebmann, B., Pfeffer, M., Friedl, A., Amon, T., 2007. Potential of biogas production in sustainable biorefinery concepts. Citeseer.

Bayr, S., Kaparaju, P., Rintala, J., 2013. Screening pretreatment methods to enhance thermophilic anaerobic digestion of pulp and paper mill wastewater treatment secondary sludge. Chem. Eng. J. 223, 479-486. doi:10.1016/j.cej.2013.02.119

Berni, M., Dorileo, I., Nathia, G., Forster-Carneiro, T., Lachos, D., Santos, B.G.M., 2014. Anaerobic Digestion and Biogas Production: Combine Effluent Treatment with Energy Generation in UASB Reactor as Biorefinery Annex. Int. J. Chem. Eng. 2014, 1-7. doi:10.1155/2014/543529, 10.1155/2014/543529

Börjesson, P., Ahlgren, S., Barta, Z., Björnsson, L., Ekman, A., Erlandsson, P., Hansson, P.-A., Karlsson, H., Kreuger, E., Lindstedt, J., Sandgren, M., Schnürer, A., Trobro, S., Villman, S., Wallberg, O., 2013. Sustainable performance of lignocellulose-based ethanol and biogas co-produced in innovative biorefinery systems (No. 87). f3 The Swedish Knowledge Centre for Renewable Transportation Fuels, Lund.

Bravo-Fritz, C.P., Sáez-Navarrete, C.A., Herrera-Zeppelin, L.A., Varas-Concha, F., 2016. Multi-scenario energy-economic evaluation for a biorefinery based on microalgae biomass with application of anaerobic digestion. Algal Res. 16, 292-307. doi:10.1016/j.algal.2016.03.028

Cardoso, S.M., Carvalho, L.G., Silva, P.J., Rodrigues, M.S., Pereira, O.R., Pereira, L., 2014. Bioproducts from seaweeds: A review with special focus on the Iberian Peninsula. Curr. Org. Chem. 18, 896-917. doi:10.2174/138527281807140515154116

Cherubini, F., Jungmeier, G., Wellisch, M., Willke, T., Skiadas, I., Van Ree, R., de Jong, E., 2009. Toward a common classification approach for biorefinery systems. Biofuels Bioprod. Biorefining 3, 534-546. doi:10.1002/bbb.172

Chinnaraj, S., Vijayakumar, T., Kumar, M.S., Subrahmanyam, S.V., 2011. Carbon footprint reduction strategies and efforts by TNPL. IPPTA Q. J. Indian Pulp Pap. Tech. Assoc. 23, 147-150.

Collet, P., Hélias, A., Lardon, L., Ras, M., Goy, R.-A., Steyer, J.-P., 2011. Life-cycle assessment of microalgae culture coupled to biogas production. Bioresour. Technol., Special Issue: Biofuels - II: Algal Biofuels and Microbial Fuel Cells 102, 207-214. doi:10.1016/j.biortech.2010.06.154

Costa, J.C., Sousa, D.Z., Pereira, M.A., Stams, A.J.M., Alves, M.M., 2013. Biomethanation Potential of Biological and Other Wastes, in: Gupta, V.K., Tuohy, M.G. (Eds.), Biofuel Technologies. Springer Berlin Heidelberg, pp. 369-396. 
Daroch, M., Geng, S., Wang, G., 2013. Recent advances in liquid biofuel production from algal feedstocks. Appl. Energy 102, 1371-1381. doi:10.1016/j.apenergy.2012.07.031

de Jong, E., Higson, A., Walsh, P., Wellisch, M., 2013. Bio-based chemicals, value added products from biorefineries.

Eriksson, 0., 2010. Environmental technology assessment of natural gas compared to biogas. INTECH Open Access Publisher.

Ersson, C., Ammenberg, J., Eklund, M., 2015. Connectedness and its dynamics in the Swedish biofuels for transport industry. Prog. Ind. Ecol. Int. J. 9, 269. doi:10.1504/PIE.2015.073416

García-Sánchez, M., Siles, J.A., Cajthaml, T., García-Romera, I., Tlustoš, P., Száková, J., 2015. Effect of digestate and fly ash applications on soil functional properties and microbial communities. Eur. J. Soil Biol. 71, 1-12. doi:10.1016/j.ejsobi.2015.08.004

González-García, S., Hospido, A., Agnemo, R., Svensson, P., Selling, E., Moreira, M.T., Feijoo, G., 2011. Environmental Life Cycle Assessment of a Swedish Dissolving Pulp Mill Integrated Biorefinery. J. Ind. Ecol. 15, 568-583. doi:10.1111/j.1530-9290.2011.00354.x

Greenbaum, P.J., 2005. The future of energy in the post-Kyoto world. Pulp Pap. Can. 106, 20-22.

Henze, M. (Ed.), 2008. Biological wastewater treatment: principles, modelling and design. IWA Pub, London.

Huang, I.B., Keisler, J., Linkov, I., 2011. Multi-criteria decision analysis in environmental sciences: Ten years of applications and trends. Sci. Total Environ. 409, 3578-3594. doi:10.1016/j.scitotenv.2011.06.022

Joelsson, E., Wallberg, O., Börjesson, P., 2015. Integration potential, resource efficiency and cost of forest-fuel-based biorefineries. Comput. Chem. Eng. 82, 240-258. doi:10.1016/j.compchemeng.2015.07.011

Kafle, G.K., Kim, S.H., Sung, K.I., 2013. Ensiling of fish industry waste for biogas production: A lab scale evaluation of biochemical methane potential (BMP) and kinetics. Bioresour. Technol. 127, 326-336. doi:10.1016/j.biortech.2012.09.032

Kamali, M., Khodaparast, Z., 2015. Review on recent developments on pulp and paper mill wastewater treatment. Ecotoxicol. Environ. Saf. 114, 326-342. doi:10.1016/j.ecoenv.2014.05.005

Kemppainen, K., Ranta, L., Sipilä, E., Östman, A., Vehmaanperä, J., Puranen, T., Langfelder, K., Hannula, J., Kallioinen, A., Siika-aho, M., Sipilä, K., von Weymarn, N., 2012. Ethanol and biogas production from waste fibre and fibre sludge - The FibreEtOH concept. Biomass Bioenergy, International Conference on Lignocellulosic ethanol 46, 60-69. doi:10.1016/j.biombioe.2012.03.027

Kouhia, M., Holmberg, H., Ahtila, P., 2015. Microalgae-utilizing biorefinery concept for pulp and paper industry: Converting secondary streams into value-added products. Algal Res. 10, 4147. doi:10.1016/j.algal.2015.04.001

Langeveld, H., Sanders, J., Meeusen, M., 2012. The Biobased Economy: Biofuels, Materials, and Chemicals in the Post-oil Era. Earthscan.

Langeveld, J.W.A., Dixon, J., Jaworski, J.F., 2010. Development Perspectives Of The Biobased Economy: A Review. Crop Sci. 50, S-142-S-151. doi:10.2135/cropsci2009.09.0529

Langlois, J., Sassi, J.-F., Jard, G., Steyer, J.-P., Delgenes, J.-P., Hélias, A., 2012. Life cycle assessment of biomethane from offshore-cultivated seaweed. Biofuels Bioprod. Biorefining 6, 387-404. doi:10.1002/bbb.1330

Lee, S.H., Ng, D.K.S., Chew, I.M.L., 2014. A Two-stage Optimization Approach for the Synthesis of an Integrated Pulp and Paper Biorefinery. Energy Procedia, International Conference on Applied Energy, ICAE2014 61, 820-823. doi:10.1016/j.egypro.2014.11.973

Lin, Y., Liang, J., Wu, S., Wang, B., 2013. Was pretreatment beneficial for more biogas in any process? Chemical pretreatment effect on hydrogen-methane co-production in a two-stage process. J. Ind. Eng. Chem. 19, 316-321. doi:10.1016/j.jiec.2012.08.018 
Martin, M., 2013. Industrial Symbiosis in the Biofuel Industry: Quantification of the Environmental Performance and Identification of Synergies.

Martin, M., 2010. Industrial Symbiosis for the development of Biofuel Production.

Martin, M., Parsapour, A., 2012. Upcycling wastes with biogas production: An exergy and economic analysis, in: Venice 2012: International Symposium on Energy from Biomass and Waste.

McKendry, P., 2002. Energy production from biomass (part 2): conversion technologies. Bioresour. Technol., Reviews Issue 83, 47-54. doi:10.1016/S0960-8524(01)00119-5

Meyer, T., Edwards, E.A., 2014. Anaerobic digestion of pulp and paper mill wastewater and sludge. Water Res. 65, 321-349. doi:10.1016/j.watres.2014.07.022

Mountraki, A., Tsakalova, M., Panteli, A., Papoutsi, A.I., Kokossis, A.C., 2016. Integrated Waste Management in Multiproduct Biorefineries: Systems Optimization and Analysis of a RealLife Industrial Plant. Ind. Eng. Chem. Res. 55, 3478-3492. doi:10.1021/acs.iecr.5b03431

Mshandete, A., Kivaisi, A., Rubindamayugi, M., Mattiasson, B., 2004. Anaerobic batch co-digestion of sisal pulp and fish wastes. Bioresour. Technol. 95, 19-24. doi:10.1016/j.biortech.2004.01.011

Murphy, J.D., Drosg, B., AllEn, E., JErnEy, J., XiA, A., Herrmann, C., 2015. A perspective on algal biogas. IEA Bioenergy 1-38.

Mussgnug, J.H., Klassen, V., Schlüter, A., Kruse, O., 2010. Microalgae as substrates for fermentative biogas production in a combined biorefinery concept. J. Biotechnol. 150, 51-56. doi:10.1016/j.jbiotec.2010.07.030

Navickas, K., Venslauskas, K., Petrauskas, A., Zuperka, V., Nekrosius, A., 2013. Biogas yields from food waste. Presented at the Engineering for Rural Development, pp. 417-422.

Näyhä, A., Horn, S., 2012. Environmental sustainability - aspects and criteria in forest biorefineries. Sustain. Account. Manag. Policy J. 3, 161-185. doi:10.1108/20408021211282304

Nitzsche, R., Budzinski, M., Gröngröft, A., 2016. Techno-economic assessment of a wood-based biorefinery concept for the production of polymer-grade ethylene, organosolv lignin and fuel. Bioresour. Technol. 200, 928-939. doi:10.1016/j.biortech.2015.11.008

Oleskowicz-Popiel, P., Kádár, Z., Heiske, S., Klein-Marcuschamer, D., Simmons, B.A., Blanch, H.W., Schmidt, J.E., 2012. Co-production of ethanol, biogas, protein fodder and natural fertilizer in organic farming - Evaluation of a concept for a farm-scale biorefinery. Bioresour. Technol. 104, 440-446. doi:10.1016/j.biortech.2011.11.060

Pfaltzgraff, L.A., Bruyn, M.D., Cooper, E.C., Budarin, V., Clark, J.H., 2013. Food waste biomass: a resource for high-value chemicals. Green Chem. 15, 307-314. doi:10.1039/C2GC36978H

Polishchuk, A., Valev, D., Tarvainen, M., Mishra, S., Kinnunen, V., Antal, T., Yang, B., Rintala, J., Tyystjärvi, E., 2015. Cultivation of Nannochloropsis for eicosapentaenoic acid production in wastewaters of pulp and paper industry. Bioresour. Technol. 193, 469-476. doi:10.1016/j.biortech.2015.06.135

Rantala, P., Väänänen, P., 1985. Cost Comparison of Aerobic and Anaerobic Wastewater Treatment Systems. Water Sci. Technol. 17, 255-255.

Ridder, M. de, 2012. Risks and opportunities in the global phosphate rock market: robust strategies in times of uncertainty. The Hague Centre for Strategic Studies, Den Haag.

Sauvée, L., Viaggi, D., 2016. Biorefineries in the bio-based economy: opportunities and challenges for economic research. Bio-Based Appl. Econ. 5, 1-4.

Schmidt, T., Pröter, J., Scholwin, F., Nelles, M., 2013. Anaerobic digestion of grain stillage at high organic loading rates in three different reactor systems. Biomass Bioenergy 55, 285-290. doi:10.1016/j.biombioe.2013.02.010

Sharma, N., Nainwal, S., Jain, S., Jain, S., 2015. Emerging biorefinery technologies for Indian forest industry to reduce GHG emissions. Ecotoxicol. Environ. Saf., Green Technologies for Environmental Pollution Control and Prevention (Part 1) 121, 105-109. doi:10.1016/j.ecoenv.2015.04.050 
Sonnenberg, A., Baars, J., Hendrickx, P., 2007. IEA Bioenergy Task 42 Biorefinery.

Suominen, K.E., Ojanen, S., Ahtila, P., 2014. A biorefinery concept for energy intensive industries focusing on microalgae and anaerobic digestion. J Mech Eng Autom 4, 242-245.

Thompson, G., Swain, J., Kay, M., Forster, C.F., 2001. The treatment of pulp and paper mill effluent: a review. Bioresour. Technol. 77, 275-286. doi:10.1016/S0960-8524(00)00060-2

Vanegas Ramirez, C.H., 2015. Biogas production from seaweed biomass : a biorefinery approach. Institute of Technology, Sligo.

Wagemann, K., 2012. Biorefineries - Prerequisite for the realization of a future bioeconomy. Presented at the DGMK Tagungsbericht, pp. 133-143.

Wang, A.-J., Li, W.-W., Yu, H.-Q., 2011. Advances in Biogas Technology, in: Bai, F.-W., Liu, C.-G., Huang, H., Tsao, G.T. (Eds.), Biotechnology in China III: Biofuels and Bioenergy, Advances in Biochemical Engineering Biotechnology. Springer Berlin Heidelberg, pp. 119-141.

Weissenberger, J., 2013. Discarding fish under the Common Fisheries Policy Towards an end to mandated waste.

Wilkie, A.C., Riedesel, K.J., Owens, J.M., 2000. Stillage characterization and anaerobic treatment of ethanol stillage from conventional and cellulosic feedstocks. Biomass Bioenergy 19, 63102. doi:10.1016/S0961-9534(00)00017-9

Wood, B.M., Jader, L.R., Schendel, F.J., Hahn, N.J., Valentas, K.J., Mcnamara, P.J., Novak, P.M., Heilmann, S.M., 2013. Industrial symbiosis: Corn ethanol fermentation, hydrothermal carbonization, and anaerobic digestion. Biotechnol. Bioeng. 110, 2624-2632.

doi:10.1002/bit.24924 